\title{
O nome de Deus em Blanchot*
}

\author{
Jean-Luc Nancy ${ }^{* *}$ \\ Universidade de Estrasburgo - França; European Graduate School - Suíça
}

Esse título não é uma provocação, e tampouco esconde uma empreitada insidiosa de captação. Não se trata de tentar deslocar Blanchot para o lado dessa nova correção (portanto indecência) política que toma a forma de um "retorno à religiáo", tâo frágil e insípido como todos os "retornos".

Trata-se somente de considerar isto: o pensamento de Blanchot é suficientemente exigente, vigilante, inquieto e alerta para não ter acreditado que deveria se ater àquilo que se impunha, no seu tempo, como uma correçáo ateia ou como um bom tom de profissão antirreligiosa. Isso não implica, no entanto, que esse pensamento tenha ficado prisioneiro, por qualquer razão que seja, de uma profissão ou de uma confissão de sentido inverso. Blanchot decerto afirma um ateísmo, mas apenas o afirma para melhor levar à necessidade de destituir conjuntamente e em confronto tanto o ateísmo quanto o teísmo.

(Isso se passa num texto maior de $A$ Conversa Infinita, no qual o ateísmo é associado à escritura ${ }^{1}$. Retornarei a isso, sem entretanto citar nem analisar tal texto, e tampouco nenhum outro: no espaço e no contexto dessa nota, não está em questão empreender uma análise. Contento-me com alusôes a alguns topoi blanchotianos no intuito de esboçar uma direção para um trabalho que virá mais tarde.)

Descartar juntos o ateísmo e o teísmo é considerar antes de tudo o ponto pelo qual o ateísmo do Ocidente (ou o duplo ateísmo do monoteísmo: aquele que ele suscita e aquele que ele oculta) até agora jamais opôs ou substituiu Deus a ou por outra coisa que não uma figura, instância ou Ideia da pontuação suprema de um sentido: de um fim, de um bem, de uma parousia - isto é, uma presença cumprida, em particular a presença do homem. É justo por esta razão que a associação do ateísmo à escritura - associação provisória e prévia à deposição conjunta de pretensões teístas e ateias - assume a aposta de deslocar o ateísmo para

* Originalmente publicado como "Le nom de Dieu chez Blanchot", em Magazine littéraire, n. 424, outubro de 2003 (número dedicado a Maurice Blanchot, intitulado: "O enigma Blanchot, o escritor da solidão essencial"); p. 66-68. Reimpresso em La Déclosion (Déconstruction du christianisme, 1). Paris: Galilée, 2005, p. 129-133. Na primeira publicação deste ensaio, no Magazine littéraire, aparece o seguinte subtítulo: "Em Blanchot, o nome de Deus não está simplesmente ausente. Ele foge e entretanto retorna, a cada vez está firmemente distanciado e é em seguida evocado em seu próprio distanciamento. Ele não designa uma existência mas a nomeação de um ausentamento do sentido." (n.t.)

** Trad. Carlos Eduardo Schmidt Capela e Vinícius Nicastro Honesko.

1. Trata-se de "L'Athéisme et l'écriture. L'Humanisme et le cri”. Traduzido para o português como "O ateísmo e a escrita. $\mathrm{O}$ humanismo e o grito", por João Moura Jr, em $A$ conversa infinita, 2: a experiência limite. São Paulo: Escuta, 2007, p. 247-271. (n.t.) 
o lado de um ausentamento de sentido, algo de que, até aqui, não foi de fato capaz nenhuma figura notável do ateísmo (a não ser em certa medida essa figura, tão próxima a Blanchot, da ateologia de Bataille - sobre a qual aqui mais nada direi).

O "sentido ausente", expressão essa algumas vezes riscada por Blanchot, não designa um sentido cuja essência, ou verdade, seria encontrada na ausência. Esta última, com efeito, ipso facto se transformaria em um modo da presença náo menos consistente do que a presença mais assegurada, mais existente. Mas um "sentido ausente" faz sentido em e por seu próprio ausentamento, de sorte que para terminar... ele náo termina de náo "fazer sentido". É assim que a "escritura" designa, em Blanchot - e nessa comunidade de pensamento que o liga a Bataille e Adorno, a Barthes e Derrida -, o movimento de exposição a essa fuga do sentido que retira do "sentido" a significaçâo para lhe dar o sentido mesmo dessa fuga - um impulso, uma abertura, uma exposição inabordável que, por conseguinte, inclusive não "foge" propriamente, que foge a fuga bem como a presença. Nem o niilismo nem a idolatria de um significado (e/ou de um significante). Eis aqui a aposta de um "ateísmo" que, em consequência, deve retirar de si mesmo a posição de negação que ele profere, e a segurança de toda espécie de presença substitutiva àquela de Deus - ou seja, aquela do significante da absoluta significação ou significabilidade.

Ora, se por acaso o texto de Blanchot é isento de qualquer interesse pela religiâo (afora o fato de que uma cultura cristá e precisamente católica transparece aqui ou ali de maneira notável, o que deverá ser examinado mais tarde), o nome de Deus, ao contrário, não está simplesmente ausente: pode-se afirmar, com precisão, que nesse texto ele ocupa o lugar muito particular de um nome que foge e que no entanto volta, que se encontra a cada vez (com pouca frequência, mas o suficiente para que seja percebido) firmemente afastado, e em seguida evocado em seu próprio afastamento, como o lugar ou como o índice de uma forma de intriga do ausentamento do sentido.

(Ainda uma vez: se aqui está fora de questão entrar nos textos, eu simplesmente sugiro que releiamos rapidamente tanto Thomas l'Obscur - primeira e segunda versão - quanto L'Entretien infini e L'Écriture du désastre, ou ainda Le dernier à parler, para neles verificar de maneira ao menos formal a presença do nome de Deus - talvez mesmo somente latente - e os aspectos manifestamente diversos, complexos, e até enigmáticos de seu papel ou de seu teor.)

Se o nome de Deus sobrevém no lugar de uma ausência do sentido, ou na linha de fuga e na perspectiva ao mesmo tempo infinita e sem profundidade de campo dessa mesma linha de fuga, é antes de tudo porque esse nome não diz respeito a uma 
existência, senão, precisamente, à nomeação - que não seria nem a designação, nem a significação - desse ausentamento. Não há aí, portanto, a justo título, nenhuma "questão de Deus" que deveria ser colocada como a questão ritual da existência ou da não-existência de um ente supremo. Semelhante questão se anula a si mesma (sabemos disso desde Kant, aliás, desde muito antes dele), posto que um ente supremo deveria ainda se encontrar em dívida com seu ser ou com o próprio ser em alguma instância ou em alguma potência (termos evidentemente muito impróprios) impossível de classificar na ordem dos entes.

Por isso o dom mais precioso da filosofia consiste, para Blanchot, não em uma operação de negação da existência de Deus, mas num simples esvaecimento, numa dissipação dessa existência. O pensamento apenas pensa a partir daí.

Blanchot assim não coloca e nem autoriza nenhuma "questáo de Deus", mas ele de vez coloca e sabe que essa questão não se coloca. O que quer dizer que ela náo é uma questão, e que ela não responde ao esquema da demanda de uma assinalação no ser (“o que é?" ou "há?"). Deus não é julgado por uma questão. O que não quer dizer que nele sobressai uma afirmação que de antemão responderia à questão. E tampouco uma negação. Não se trata de saber se há ou não há Deus. É, bem diferente, que há ou, sobretudo, que se pronuncia o nome de Deus. Esse nome responde a uma deposição da questão, seja a questão do ser (o quê?), a questáo da origem (por meio de quê?) ou a questão do sentido (por que?). Se toda questão visa a um "quê", qualquer coisa, o nome de deus responderia à ordem, ao registro ou à modalidade daquilo que não é ou, ainda, daquilo que não tem coisa alguma.

Nesse sentido, aliás, esse nome em Blanchot por vezes acompanha palavras como "ser" (tal como retomada de Heidegger) ou "neutro". Tampouco para elas a questão se coloca, uma vez que ela já está, nelas, deposta. Mas são palavras (conceitos), enquanto "Deus" é um nome (sem conceito). O nome de Deus deve, portanto, representar aqui outra coisa que náo um conceito, e, mais precisamente, ele deve trazer e tornar mais agudo um traço próprio ao nome como tal: a extremidade e a extenuação da significação.

Sem dúvida, com esse nome acontece o mesmo que com o de Thomas, que poderíamos qualificar de herói epônimo da escritura blanchotiana. No relato intitulado Thomas l'Obscur, ao longo do qual o nome de Deus aparece e opera em distintas oportunidades, o nome de Thomas por vezes se encontra designado como "a palavra Thomas". A palavra thauma, em grego, significa a maravilha, o prodígio, o milagre. Enquanto conceito, "Thomas" apresenta o milagre ou o mistério do nome enquanto nome. 
O nome de Deus é dito por Blanchot, em algumas ocasióes, "demasiado imponente". Essa qualificação mesclada de temor ou de reverência abre duas interpretaçóes. Ou esse nome impóe-se em demasia porque pretende impor e se impor como a pedra angular de um sistema completo do sentido, ou ele é majestoso e temido na medida em que revela a não significância dos nomes. No segundo caso esse nome nomeia uma potência soberana do nome pela qual ele faz signo - o que difere totalmente de significar - em direçấo a esse ausentamento do sentido, de modo tal que nenhuma ausência possa daí vir a suprir uma presença supostamente perdida ou recusada. "Deus" então não nomearia nem o Deus sujeito do sentido, nem a negaçáo deste último em favor de um outro sujeito do sentido ou ainda do não-sentido. "Deus" nomearia aquilo - aquele ou aquela - que no nome escapa à própria nomeação, mesmo que esta possa sempre confinar o sentido. Assim, esse nome des-nomearia o nome em geral, persistindo mesmo assim em nomear, isto é, em chamar. O que é chamado e em direção ao que ele é chamado não é em nenhuma hipótese de uma outra ordem senão aquela que Blanchot designa por vezes como "o vazio do céu". Mas o chamado a tal vazio, e nele, introduz nesse nome uma sorte de pontuação última ainda que sem última palavra... - a esse abandono do sentido que forma tão bem a verdade de um abandono ao sentido em que este último se excede. O nome de Deus assinalaria ou proferiria esse chamado.

Na conjunção do ateísmo e da escritura Blanchot conjuga, no mesmo texto e no mesmo título, aquela do humanismo e do grito. O humanismo do grito seria o humanismo que abandona toda idolatria do homem e toda antropoteologia. Se não é exatamente no registro da escritura, também não é naquele do discurso - mas no do grito. Precisamente, "ele grita no deserto", escreve Blanchot. Não é por acaso que ele retoma uma fórmula insigne do profetismo bíblico. O profeta é aquele que fala por Deus e de Deus, aquele que anuncia aos outros o chamado e a lembrança de Deus. Nenhum retorno à religiáo se insinua dessa maneira: não obstante, tenta-se extrair da herança monoteísta seu traço essencial e essencialmente náo religioso, o traço de um ateísmo ou daquilo que poderíamos nomear um ausenteismo para além de toda posição de um objeto de crença ou de descrença. Quase apesar dele, e como sobre o limite extremo de seu texto, Blanchot náo cedeu ao nome de Deus - ao inaceitável nome de Deus -, pois soube que era preciso ainda nomear o chamado inominável, o chamado interminável à inomeação. 